\section{Inequalities in access and utilization of dental services: a cross-sectional study in an area covered by the Family Health Strategy}

\author{
Desigualdades no acesso e utilização de serviços \\ odontológicos: estudo transversal em uma área \\ atendida pela Estratégia Saúde da Família
}

Márcia Helena Baldani 1

José Leopoldo Ferreira Antunes 2

\footnotetext{
1 Departamento de Odontologia, Universidade Estadual de Ponta Grossa, Ponta Grossa, Brasil.

2 Faculdade de Saúde Pública, Universidade de São Paulo, São Paulo, Brasil.

Correspondence M. H. B. Pinto

Departamento de Odontologia, Universidade Estadual de Ponta Grossa.

Av. Carlos Cavalcante 4748, bloco M, Ponta Grossa, PR 84030-000, Brasil. mbaldani@uepg.br
}

\begin{abstract}
This cross-sectional study aimed to investigate the presence of inequalities in the access and use of dental services for people living in the coverage area of the Family Health Strategy (FHS) in Ponta Grossa, Paraná State, Brazil, and to assess individual determinants related to them. The sample consisted of 747 individuals who answered a pre-tested questionnaire. Data analysis was performed by chi-square test and Poisson regression analysis, obtaining explanatory models for recent use and, by limiting the analysis to those who sought dental care, for effective access. Results showed that $41 \%$ of the sample had recent dental visits. The lowest visit rates were observed among preschoolers and elderly people. The subjects who most identified the FHS as a regular source of dental care were children. Besides age, better socioeconomic conditions and the presence of a regular source of dental care were positively associated to recent dental visits. We identified inequalities in use and access to dental care, reinforcing the need to promote incentives to improve access for underserved populations.
\end{abstract}

Health Services Accessibility; Oral Health; Health Inequalities

\section{Introduction}

Oral diseases mostly affect disadvantaged people 1 , who are less likely to receive dental care and more likely to have unmet needs than those in better social conditions 2,3,4. Inequalities in access to dental services have been identified in several countries, regardless of the nature, scope and efficiency of their health systems 3,5,6,7,8. The social gradient of oral health can also be observed when the deprived people are subject to health services not specifically prepared to deal with their actual needs 4 .

In Brazil, the most comprehensive information on access to dental services is provided by the health supplements of the National Household Sample Survey (PNAD) carried out in 1998 , 200310 and 2008 11. The results of the PNAD 1998 showed that $18.7 \%$ of the Brazilian people had never consulted a dentist, and that this proportion was eight times higher for the lower-income group (39\% versus 5\%). Larger socioeconomic differentials were found among very young and old subjects 2,9. Subsequent information (PNAD 2003: 15.9\%; PNAD 2008: $11.7 \%$ ) recorded a declining trend for this group. Notwithstanding, inequalities in the access to dental services persisted, or even grew, as the proportion of those who have never consulted a dentist, among individuals with lower and higher incomes were, respectively, $31 \%$ and $3 \%$ in 2003 and $28.7 \%$ and $2 \%$ in 2008 10,11. Information related to the three PNAD 
surveys also revealed that the number of people who had recently visited a dentist (less than one year ago) were higher for the better income group (67.2\% versus $28.5 \%$ in 2008) 10,11 .

Measuring access to health services is fundamental to instruct health policies. It allows forecasting the effective use of health services; it contributes to the promotion of social justice, and it contributes to improve the effectiveness and efficiency of health services 12 . The concept of access to health services is complex and allows integrating the perception of health needs with the demand and effective use of services 13 . This implies that people use health services at "proportional and appropriate" rates to their existing need for care ${ }^{14}$. Andersen and Davidson 12 defined access as the actual use of health services and everything that facilitates or impedes their use. The concept is thus multidimensional, and encompasses both individual aspects and characteristics related to the organization of health services. "Potential access" to health services was defined as the resources that enable the use and increase the likelihood that it will take place; and the "realized access" represents the actual use of the services, which is influenced by other issues in addition to enabling factors, and reflect the perceived need of individuals and their societal determinants 12 . Therefore, the use of health services is influenced by individual factors, by characteristics of the health system, the social context, and the past experience with using services 12,14 .

The possibility of inclusion, since the year 2000, of oral health services in the Family Health Strategy (FHS), added to the current programmatic guidance proposed by the recent National Oral Health Policy, aims to shift the traditional model of public dental services delivery, which had always been centered on emergency care or targeted to priority groups (school aged children), by extending the possibilities of access to oral health care to the entire population. Theoretically, this new organization should increase access and promote the regular use of dental services for the low-income population living in the FHS coverage areas, minimizing the unmet demand 15 .

In the last years, the provision and use of dental services in the FHS have been evaluated by some studies, which tried to assess its potential as an inclusive policy. At the aggregate level, Baldani et al. 16 identified redistributive trends in the allocation of financial resources and provision of public dental services among the municipalities of the Paraná State (Southern Brazil), which were positively associated with the presence of dental teams in the FHS. However, Souza \& Roncalli 17 had observed, for some large municipalities of the Rio Grande do Norte State (Northeastern Brazil), that only those with better socioeconomic status had really experienced an increase in quality after the introduction of oral health services in the FHS. At the individual level, the few studies conducted so far have pointed to the persistence of inequalities in the access and use of dental services in the FHS, highlighting an unfavorable condition for populations with poor social conditions 18,19.

Health care systems aim to maintain and improve health outcomes. This goal can only be achieved when instructed by adequate knowledge on how people use health services and what factors are associated with their use 8 . The aim of this study is to investigate the presence of inequalities in the access and use of dental services for people (all ages) living in the coverage area of the FHS in Ponta Grossa, a city in the Paraná State. This study also aimed to assess individual determinants related to the access and use of dental services.

\section{Methods}

This cross-sectional study was approved by the Ethics Research Committee of the Ponta Grossa State University (Universidade Estadual de Ponta Grossa - UEPG). All individuals were informed of the objectives of the study, and freely agreed to participate. They were also informed that no personal information would be identified. The target population comprised individuals living in the working areas of the dental teams of the FHS in Ponta Grossa, a city with nearly 311,000 inhabitants, located in the state of Parana, southern Brazil. The population registered for the program in 2005, the year when the survey was designed, corresponded to 32.7 percent of the total population of the city, and was composed of people who lived in its poorest areas. There were 29 family health teams (FHT) and 14 corresponding dental teams (FHDT) working in these areas.

The sample size was calculated considering a maximum error of $5 \%$, significance level of $95 \%$, and the number of individuals enrolled in the FHS in the city. Dental service utilization was estimated at $12 \%$, which is the proportion of patients seen by the dental teams in the FHS in 2004, in relation to the total population registered in this program, according to official reports of the municipal health department. Since no information was available by age, the rate of total prevalence was used to calculate the sample size for each age group.

The final sample consisted of 747 individuals, stratified according to four age subgroups about which information was available in official databases, namely the Primary Health Care 
Information System (SIAB): (a) babies and preschool children (0 to 6 years of age); (b) school children ( 7 to 14 years of age); (c) adults (15 to 59 years of age), and d) elderly people (60 years of age and older). The SIAB aggregates data for the population enrolled in the FHS, as well as health actions developed by community health workers (ACS) and other workers. It represents an important source of data for diagnosing the health status of the population in a certain area, guiding the planning and evaluation of health interventions. The decision to include all age groups of SIAB in the sample design was consistent with the criterion of universal access to individuals of all ages and conditions of risk, which is observed by the Brazilian Unified National Health System (SUS) and its FHS programs 20 and National Oral Health Policy 21.

The selection of participants observed a complex sample design, according to information collected during the registration of families by the ACS, and included all people living in the coverage areas, even those not registered at family health facilities. In the first stage, eight FHS dental teams' coverage areas were randomly selected, maintaining the proportionality between the health teams: 1 FHDT: 1 FHT (encompassing nearly 4,000 registered persons each) and 1 FHDT: 2 FHT (near 8,000 registered persons each). For each FHT, two ACS predefined working areas were randomly selected and, for each of them, 50 households were included. All individuals dwelling in the selected households were invited to participate in the study; those who agreed to participate signed an informed consent form. The methodology was previously applied in a pilot study, which was conducted in one of the unselected ACS working areas and enrolled a sample of 50 people. A low response ratio (50\%) was observed in the pilot study, which was attributed to the absence of subjects during the visit of the researcher, a high turnover of families in the homes and, to a lesser extent, geographic limitations and the risk of violence. Taking these limitations into consideration, the sample size was doubled.

Data were gathered from August 2007 to June 2008, by ten Dental and Nursery students from the Universidade Estadual de Ponta Grossa, some of whom received research scholarships. They received training in applying the questionnaire and techniques to deal with families during home visits, and they conducted the interviews under the supervision of the main researcher. Interviewers were supported by the ACS, who were responsible for leading them to the selected households and to introduce them to their residents. The involvement of the ACS at all stages of the research was a requirement of the City Health
Department, concerned about the safety of the research team. If the selected persons were not located at home during the visit, one additional attempt was made on a subsequent day and at a different time.

The individuals who were interviewed answered a questionnaire on their socioeconomic conditions, perceived need and access to dental treatment. The questionnaire was adapted from the Heath Supplement in PNAD 2003 10. For children younger than 11 years, the mother or other guardian was asked to answer the questionnaire.

This study adopted the concept of access as involving perceived need, demand and effective use of dental services 13 . The assessment of factors associated with access to dental services considered the explicative model proposed by Andersen \& Davidson ${ }^{12}$. The report of recent dental visits was the first outcome variable of this study. The recall period was the 12 months that preceded the interview, as indicated for in-patient care in the analysis of public health care utilization 22 . Exclusively considering those that sought dental treatment during the three months that preceded the interview, the second outcome variable of the study identified individuals who effectively had access to these services

The conceptual framework used to select independent variables was based on the individual determinants of health service utilization from Andersen's Behavioral Model 23. This model postulates that the use of health services is a function of the individual's predisposition to use them (which is influenced by socio demographic characteristics, preferences and expectations regarding oral health, and knowledge of the dental care delivery system), the level of need (perceived health status, severity of disease, limitations of activity), and the presence of factors that enable or facilitate the utilization of the services (income, social networks, access to a regular source of care) 23 .

Covariateswereselected accordingto the three dimensions of the model. The predisposing factors were represented by the socio-demographic variables: (a) unmodifiable: age and gender; (b) modifiable: ownership of the family's house. The need for health care was assessed based on the individual's self-rated oral health condition and reported need of dental care. The information was complemented by asking the respondents about the presence of oral problems and, if so, inviting them to specify the problem. As enabling factors, the chosen variables were: (a) related to the family level: family monthly income (the cutoff point being the Brazilian minimum wage); (b) related to the level of services: being registered at the FHS, having a regular source of dental care 
and the kind of health services being referenced (public or private). The services related enabling variables were constructed from the answers to the following questions: "Are you regularly visited by the ACS?"; "In case of necessity or for a routine check-up, is there a dentist that you regularly visit?"; and "When you need dental care, which kind of service do you usually seek?".

The data analysis involved using SPSS for Windows version 15.0 (SPSS Inc., Chicago, USA) and Stata for Windows version 10 (Stata Corp., College Station, USA). Initially, the outcome variables and covariates were described as stratified by age groups. The assessment of association used the chi-square test. Subsequently, Poisson regression models assessed unadjusted and adjusted associations, as measured by prevalence ratios and respective $95 \%$ confidence intervals 24 .

\section{Results}

The final sample of this study involved 747 individuals, aged between zero and 88 . Among the individuals selected from the ACS working areas that were included, the non-participation rate was $12 \%$. The highest non-participation rates occurred among older adults (35 years of age or more) and the elderly (24\%). The mean per capita monthly income was U\$ 106.54 ( \pm U\$ 93.30), slightly above the Brazilian poverty line (half the official minimum wage per capita per month); $20 \%$ of households reported a total monthly income of one minimum wage or less, and $73 \%$ of them had a total monthly income of between one and three times the minimum wages. One official minimum monthly wage was equivalent to US\$ 191.00, at the end of the gathering of data.

Table 1 describes the distribution of the population according to study variables in each age group. The participation of women was more prevalent (65\% overall), mainly among adults and the elderly. Age groups presented relatively homogeneous family income, though a larger proportion of elderly people reported the ownership of their houses. There were significant differences among age groups regarding the selfperception of oral health. The proportions of subjects reporting the need for dental care were high for all age groups, reaching $74 \%$ among adults. Nevertheless, the oldest and youngest age groups reported higher levels of satisfaction with their oral health status and less need for dental treatment. Although $10.3 \%$ of the sample made reference to dental pain, the prevalence was statistically higher for adults (18.2\%), while it ranked from $6.5 \%$ to $7.4 \%$ among other groups (nontabulated data).
Table 1 shows that $91 \%$ of respondents were registered at FHS facilities and were regularly visited by the ACS. Approximately $81 \%$ reported using FHS services, but only $67 \%$ had their health problems longitudinally monitored by the FHT (results not shown in the Table). Among the respondents, $48 \%$ reported having a regular source of dental care, with schoolchildren (58\%) and adults (56\%) being those who most reported having a regular dentist (Table 1). Children made up the largest proportion of respondents who identified the FHDT as their regular source of dental care (36\% and $44 \%$ ), whereas the highest proportion of individuals mentioning other sources, mainly private dentists and dental insurance, occurred in the adults group (34\%). When asked about the main reasons for not using FHS dental services, the majority of respondents reported difficulties in getting a vacancy or scheduling an appointment with the FHDT, or even the opening hours (information not included in Table 1).

Table 1 also describes the utilization of dental services by the study population: $41 \%$ of respondents reported visiting a dentist in the year before the survey and $15 \%$ had never done so. These results varied according to age groups, with the highest proportions of recent use of dental care being observed among schoolchildren and adults (55\% and $47 \%$ respectively) and the lowest among older people (19\%). For children aged 0-6 years the prevalence of ever having made a dental visit was $50 \%$. Considering the total sample, 163 subjects (22\%) sought dental treatment in the three months preceding the interviews, and the lowest proportion was found among the elderly (12\%). The greatest proportion of demand of the FHDT services was found in the group of preschool children, and the largest demand of other source of dental care in the group of adults. Routine and preventive procedures were the main reasons for seeking dental care in the group of preschoolers, and toothache was the main reason for the other age groups. Among the individuals who demanded dental care, 131 (80\%) obtained it, and no significant differences were found between age groups (results not shown in the Table).

Table 2 synthesizes the unadjusted and adjusted associated factors with recent use of dental services. In the unadjusted analysis the use of dental services in the year before the survey was significantly associated with age, with elderly people having a poorer profile. In the other age groups, the prevalence ranked higher for schoolchildren, with almost three times more dental visits than the elderly. Socioeconomic variables were significantly associated with the outcome, with a higher proportion of recent consultations 
Table 1

Proportional distribution of the sample. including total and by age group. by gender. socioeconomic status. perceived need. service features. access and use. Coverage area of the Family Health Strategy (FHS). Ponta Grossa, Paraná State, Brazil, 2007-2008.

\begin{tabular}{|c|c|c|c|c|c|c|}
\hline \multirow[t]{2}{*}{ Variables (number of answers) } & \multirow{2}{*}{$\begin{array}{c}\text { Total } \\
\text { sample (\%) }\end{array}$} & \multicolumn{4}{|c|}{ Age group (\%) } & \multirow[t]{2}{*}{ p-value * } \\
\hline & & $\begin{array}{c}0-6 \\
(n=184)\end{array}$ & $\begin{array}{c}7-14 \\
(n=168)\end{array}$ & $\begin{array}{c}15-59 \\
(n=239)\end{array}$ & $\begin{array}{c}\geq 60 \\
(n=155)\end{array}$ & \\
\hline \multicolumn{7}{|l|}{ Gender $(n=747)$} \\
\hline Female & 65.2 & 46.2 & 57.5 & 82.0 & 69.7 & $\mathrm{~S}$ \\
\hline Male & 34.9 & 53.8 & 42.3 & 18.0 & 30.3 & \\
\hline \multicolumn{7}{|l|}{ Monthly family income $(n=706)$} \\
\hline Low (more than US\$191) & 80.4 & 81.7 & 80.7 & 83.6 & 74.0 & NS \\
\hline Very low (US\$ 191 or less) & 19.7 & 18.3 & 19.3 & 16.4 & 26.0 & \\
\hline \multicolumn{7}{|c|}{ Ownership of the family's house $(n=723)$} \\
\hline Yes & 80.9 & 76.7 & 81.8 & 77.9 & 89.7 & $\mathrm{~S}$ \\
\hline No & 19.1 & 23.3 & 18.2 & 22.1 & 10.3 & \\
\hline \multicolumn{7}{|l|}{ Perception of oral health status } \\
\hline Very good/Good & 64.3 & 81.6 & 62.5 & 50.8 & 69.5 & $\mathrm{~S}$ \\
\hline Bad/Very bad & 35.7 & 18.4 & 37.5 & 49.2 & 30.5 & \\
\hline \multicolumn{7}{|l|}{ Need for dental care } \\
\hline No & 42.4 & 54.7 & 35.9 & 25.8 & 62.3 & $\mathrm{~S}$ \\
\hline Yes & 57.6 & 45.3 & 64.1 & 74.2 & 37.7 & \\
\hline \multicolumn{7}{|l|}{ Regularly visited by the ACS } \\
\hline No & 90.7 & 91.3 & 93.6 & 88.8 & 87.2 & NS \\
\hline Yes & 9.3 & 8.7 & 6.4 & 11.2 & 12.8 & \\
\hline \multicolumn{7}{|l|}{ Referal to a regular dentist $(n=731)$} \\
\hline Yes & 48.3 & 50.9 & 58.1 & 56.4 & 37.7 & $\mathrm{~S}$ \\
\hline FHS & 30.2 & 36.4 & 44.2 & 22.6 & 20.1 & $\mathrm{~S}$ \\
\hline Other services & 18.1 & 14.5 & 13.9 & 33.8 & 17.5 & $\mathrm{~S}$ \\
\hline No & 51.7 & 49.1 & 41.8 & 53.6 & 62.3 & \\
\hline \multicolumn{7}{|c|}{ Kind of reference dental service. regular or not $(n=711)$} \\
\hline Public & 82.6 & 86.6 & 92.6 & 74.3 & 80.1 & $\mathrm{~S}$ \\
\hline Private & 17.4 & 13.3 & 7.4 & 25.6 & 19.9 & $\mathrm{~S}$ \\
\hline \multicolumn{7}{|l|}{ Last dental visit $(n=747)$} \\
\hline Less then one year ago & 41.4 & 40.2 & 55.4 & 47.1 & 18.7 & $\mathrm{~S}$ \\
\hline 1 or 2 years ago & 19.4 & 8.7 & 28.0 & 25.8 & 12.9 & $\mathrm{~S}$ \\
\hline 3 or more years ago & 24.0 & 0.5 & 8.3 & 26.7 & 64.5 & $\mathrm{~S}$ \\
\hline Never had a dental visit & 15.3 & 50.5 & 8.3 & 0.4 & 3.9 & $\mathrm{~S}$ \\
\hline \multicolumn{7}{|c|}{ Sought dental services in the last 3 months $(n=736)$} \\
\hline Yes & 22.2 & 24.0 & 22.6 & 26.7 & 12.4 & $\mathrm{~S}$ \\
\hline FHS & 11.4 & 15.1 & 11.9 & 11.9 & 5.2 & $\mathrm{~S}$ \\
\hline Other services & 9.5 & 7.3 & 8.9 & 14.0 & 5.9 & $\mathrm{~S}$ \\
\hline Answer not given & 1.2 & 1.7 & 1.8 & 0.8 & 1.3 & NS \\
\hline No & 77.8 & 76.0 & 77.4 & 73.7 & 87.6 & \\
\hline
\end{tabular}

ACS: community health workers; NS: non-significant difference; S: statistically significant difference.

* Qui-square test

Note: US\$1.00 = R\$2.25 (nov/2008). 
Unadjusted and adjusted analysis for recent use of dental services by people living in the coverage area of the Family Health Strategy (FHS). Ponta Grossa, Paraná State, Brazil, 2007-2008.

\begin{tabular}{|c|c|c|c|c|c|}
\hline & \multirow[t]{2}{*}{ Prevalence (\%) } & \multicolumn{4}{|c|}{ Used dental services in the previous year * } \\
\hline & & $\begin{array}{c}\mathrm{RP}_{\text {unadjusted }} \\
(95 \% \mathrm{Cl})\end{array}$ & p-value & $\mathrm{RP}_{\text {adjusted }}(95 \% \mathrm{Cl})$ & p-value \\
\hline \multicolumn{6}{|l|}{ Predisposing factors } \\
\hline \multicolumn{6}{|l|}{ Age group (years) } \\
\hline 60 and older & 18.7 & 1.00 & & 1.00 & \\
\hline $15-59$ & 47.1 & $2.50(1.76-3.57)$ & $<0.001$ & $2.40(1.69-3.41)$ & $<0.001$ \\
\hline $7-4$ & 55.4 & $2.96(2.07-4.22)$ & $<0.001$ & $2.71(1.90-3.87)$ & $<0.001$ \\
\hline $0-6$ & 40.2 & $2.15(1.48-3.12)$ & $<0.001$ & $2.11(1.47-3.05)$ & $<0.001$ \\
\hline \multicolumn{6}{|l|}{ Gender } \\
\hline Female & 39.7 & 1.00 & & & \\
\hline Male & 44.2 & $1.11(0.93-1.33)$ & 0.228 & & \\
\hline \multicolumn{6}{|l|}{ Home ownership } \\
\hline Yes & 43.5 & 1.00 & & 1.00 & \\
\hline No & 31.9 & $0.73(0.56-0.95)$ & 0.020 & $0.74(0.58-0.95)$ & 0.019 \\
\hline \multicolumn{6}{|l|}{ Need factors } \\
\hline \multicolumn{6}{|l|}{ Perception of oral health status } \\
\hline Very good/Good & 41.1 & 1.00 & & & \\
\hline Bad/Very bad & 42.4 & $1.03(0.87-1.23)$ & 0.716 & & \\
\hline \multicolumn{6}{|l|}{ Need dental care } \\
\hline No & 35.6 & 1.00 & & & \\
\hline Yes & 44.9 & $1.26(1.04-1.52)$ & 0.016 & & \\
\hline \multicolumn{6}{|l|}{ Enabling factors } \\
\hline \multicolumn{6}{|l|}{ Family monthly income } \\
\hline Low (more than US\$191) & 43.6 & 1.00 & & 1.00 & \\
\hline Very low (US\$ 191 or less) & 30.4 & $0.70(0.53-0.91)$ & 0.009 & $0.77(0.59-1.01)$ & 0.060 \\
\hline \multicolumn{6}{|l|}{ Regularly visited by the ACS } \\
\hline No & 46.9 & 1.00 & & & \\
\hline Yes & 40.6 & $0.86(0.66-1.14)$ & 0.308 & & \\
\hline \multicolumn{6}{|l|}{ Referral to a regular dentist } \\
\hline No & 29.3 & 1.00 & & 1.00 & \\
\hline Yes & 55.3 & $1.89(1.57-2.27)$ & $<0.001$ & $1.72(1.44-2.06)$ & $<0.001$ \\
\hline \multicolumn{6}{|c|}{ Kind of reference dental service. regular or not } \\
\hline Private & 49.2 & 1.00 & & & \\
\hline Public & 40.6 & $0.83(0.67-1.01)$ & 0.066 & & \\
\hline
\end{tabular}

95\% Cl: 95\% confidence interval; ACS: community health workers.

* Individuals included in the analysis - total sample of the survey $(n=747)$.

among individuals whose families owned their own home (a predisposing factor) and those in the higher income group (an enabling factor). A higher proportion of participants stating recent use of dental services was observed among people who reported the need for dental care. Regarding service variables, the fact of being registered at the FHS was not associated to recent dental visits; notwithstanding, the prevalence of use of dental services in the previous year was higher for those who had a regular source of dental care. Higher proportions of recent dental visits were found among those who reported that they would seek private dental services if necessary. This association was statistically significant at the level of $10 \%$ ( $p=0.066)$. After adjusting the model, only variables pertaining to the groups of predisposing and enabling factors remained associated with the outcome. The elderly people, the individuals whose families did not own their 
household and those with lower income had poorer rates of recent use. The fact of having a regular dentist remained positively associated with the outcome.

Table 3 presents the results of the unadjusted and adjusted associations, considering only those individuals who demanded dental services in the three months before the interviews. In this case, the predisposing factors were not associated with having actually used dental services. Those reporting poor oral health (need factor), in the lower income group, and those who indicated public services as the reference for dental treatment (enabling factors) had a lower prevalence of use. The two latter covariates were associated to the outcome at the $10 \%$ level of statistical significance $(p=0.080$ and $p=0.066$, respectively). The multivariate model included the perception of one's oral health condition and the kind of reference dental services, which remained borderline significant at $5 \%(\mathrm{p}=0.058)$.

\section{Discussion}

The study of inequalities in the access and utilization of health services must involve assessing the overall population, independently of their records in the health system, thus identifying possible sources of exclusion 22 . This household survey provided a preliminary insight on patterns and determinants of dental service access and utilization by residents in the working area of the FHS in the city of Ponta Grossa. The increasing knowledge on factors influencing dental service utilization may lead to equitable and more effective policies. Differential implementation of the FHS according to population size and discrepant political and programmatic guidelines of municipal governments prevent current results from being extrapolated to other locations.

We identified inequalities in dental service utilization according to age, and the specific related determinants were exploited apart, in three other manuscripts 25,26,27. Preschool children and elderly people reported lower proportions of dental visits in the 12 months that preceded the survey. This result is consistent with official nationwide research (PNAD 1998, 2003, 2008) 9,10,11 and the latest survey on oral health status conducted by the Brazilian Ministry of Health (Ministério da Saúde) - SB Brazil 28. The proportion of individuals who reported having visited a dentist in the year preceding the interview was similar to those described by PNAD 2008 (40\%) 11. Comparing with another city in southern Brazil, the prevalence of recent dental visits among adolescents, adults and the elderly in Ponta Grossa (42\%) was worse than in Pelotas, Rio Grande do Sul State (51\%) 26. For both studies, rates of utilization were similar for adolescents, and more accentuated differences affected adults and the elderly. However, in Pelotas, the sample design included the whole urban population, while the current study exclusively included the low-income population, given the characteristics of the FHS 29.

The proportion of individuals who had never been to the dentist was higher than the figure reported by the PNAD 2003 for the State of Paraná (10.1\%) 10 and by the PNAD 2008 for the whole country $(11,7 \%) 11$. As expected, a higher prevalence was found among preschool children, which was lower than the prevalence reported by the PNAD 2008 for Brazil (77.9\%) 11. The results related to preschool children ranked similarly to those observed in Sobral, Ceará State, for children between 5 and 9 years of age (49.1\%) 30 , and lower than the figure observed among preschool children in Canela, Rio Grande do Sul State (87\%) 31. These differences possibly reflect specific features of public service organizational guidelines for municipalities.

The recent use of dental services was directly associated with family income and the home ownership, which indicates socioeconomic inequalities in the access to dental services. Socioeconomic inequalities were also reported by PNAD 2008 11, with $28.5 \%$ of Brazilians with a monthly income of one minimum wage or less having recently visited the dentist; in this study, this figure was $30 \%$. This percentage ranked lower than figures related to the population reporting a higher income (43.6\%). The socioeconomic gap in the access to dental services in areas covered by the FHS had previously been identified in a study conducted in Campina Grande, a city in the Northeastern state of Paraíba 18. Individuals who reported the preferential use of private dental services had a higher rate of access in the three months that preceded the interview; a difference considered to be of borderline statistical significance. A higher rate of access among those who use private services or have health insurance was also reported by other studies in Brazil 30,32,33.

Self-perception of oral health has been considered an indicator of behavior related to the demand for health services. The most recent countrywide dental survey performed in Brazil highlighted dental pain as one of the main reasons for recent visits to the dentist 28,34. Dental pain was the most cited reason for the recent demand of dental services in this study, except for preschoolers. Regression models indicated an inverse association between variables 
Unadjusted and adjusted analysis for access to dental services among people living in the coverage area of the Family Health Strategy (FHS). Ponta Grossa, Paraná State, Brazil, 2007-2008.

\begin{tabular}{|c|c|c|c|c|c|}
\hline & \multirow[t]{2}{*}{ Prevalence (\%) } & \multicolumn{4}{|c|}{ Sought dental services in the last 3 months and actually used them * } \\
\hline & & $\mathrm{RP}_{\text {unadj }}(95 \% \mathrm{Cl})$ & p-value & $\mathrm{RP}_{\text {adj }}(95 \% \mathrm{Cl})$ & p-value \\
\hline \multicolumn{6}{|l|}{ Predisposing factors } \\
\hline \multicolumn{6}{|l|}{ Age group (years) } \\
\hline 60 and over & 78.9 & 1.00 & & & \\
\hline $15-59$ & 73.4 & $0.93(0.71-1.23)$ & 0.607 & & \\
\hline $7-14$ & 86.5 & $1.09(0.84-1.43)$ & 0.501 & & \\
\hline $0-6$ & 86.0 & $1.09(0.84-1.42)$ & 0.520 & & \\
\hline \multicolumn{6}{|l|}{ Gender } \\
\hline Female & 80.2 & 1.00 & & & \\
\hline Male & 80.6 & $1.01(0.86-1.18)$ & 0.944 & & \\
\hline \multicolumn{6}{|l|}{ Home ownership } \\
\hline Yes & 79.0 & 1.00 & & & \\
\hline No & 85.0 & $1.08(0.88-1.32)$ & 0.480 & & \\
\hline \multicolumn{6}{|l|}{ Need factors } \\
\hline \multicolumn{6}{|l|}{ Perception of oral health status } \\
\hline Very good/Good & 88.9 & 1.00 & & 1.00 & \\
\hline Bad/Very bad & 67.2 & $0.76(0.63-0.91)$ & 0.003 & $0.75(0.63-0.91)$ & 0.003 \\
\hline \multicolumn{6}{|l|}{ Need dental care } \\
\hline No & 91.7 & 1.00 & & & \\
\hline Yes & 72.6 & $1.13(0.80-1.59)$ & 0.477 & & \\
\hline \multicolumn{6}{|l|}{ Enabling factors } \\
\hline \multicolumn{6}{|l|}{ Family monthly income } \\
\hline Low (more than US\$191) & 83.7 & 1.00 & & & \\
\hline Very low (US\$ 191 or less) & 64.0 & $0.76(0.56-1.04)$ & 0.080 & & \\
\hline \multicolumn{6}{|l|}{ Regularly visited by the ACS } \\
\hline No & 71.4 & 1.00 & & & \\
\hline Yes & 80.9 & $1.13(0.80-1.59)$ & 0.477 & & \\
\hline \multicolumn{6}{|l|}{ Referal to a regular dentist } \\
\hline No & 77.6 & 1.00 & & & \\
\hline Yes & 81.9 & $1.06(0.89-1.25)$ & 0.521 & & \\
\hline \multicolumn{6}{|c|}{ Kind of dental service of reference. regular or not } \\
\hline Private & 90.0 & 1.00 & & 1.00 & \\
\hline Public & 78.1 & $0.87(0.75-1.01)$ & 0.066 & $0.87(0.75-1.00)$ & 0.058 \\
\hline
\end{tabular}

95\% Cl: 95\% confidence interval; ACS: community health workers.

* Individuals included in the analysis - people who demanded dental services in the 3 months before the interviews $(n=163)$.

related to need factors and both recent use and access to dental care. With regard to recent use (Table 2), the need for dental care was not included in the multivariate model, which is consistent with results reported by Rocha \& Goes 18 for Campina Grande, in a study that exclusively included socio-demographic variables in the final multivariate model. With regard to access to dental care (Table 3), a poor perception of oral health was the only variable significantly associated with not having obtained dental care.
Having a regular source of care is important to implement the access to health services $35,36,37,38$. Ryan et al found that, among American adolescents from urban and rural areas, having a regular source of health care was the most significant predictor for use of all types of health services, including dental services 35,38 . Similar results were observed in Brazil in a big city in the state of Rio Grande do Sul 37. In the present study, having a regular source of dental care was identified as a factor that enables the recent use of den- 
tal services and was strongly associated with this outcome in the multivariate analysis (Table 2).

Notwithstanding the fact that guaranteeing access to dental teams is an important objective of the FHS, this study identified no association between receiving regular visits from the ACS and both access and use of dental services. Rocha \& Goes 18 didn't find any association between living in areas covered by the FHS and access to dental services among adult and elderly populations. Pereira et al. 19 compared the rates of use of dental services among adults and elderly people covered by the FHS with dental teams and those covered by FHS without dental teams in Natal, Rio Grande do Norte State, and found an increased number of dental visits in areas without FHDT. In both studies, authors suggested that the inclusion of dental teams in the FHS may not have changed the traditional pattern of dental care organization, which remained focused on actions targeted at children. This hypothesis is consistent with results of this study. As noted in Table 1, subjects that most identified the FHS as a regular source of dental care were school and preschool children. This latter group had also the highest proportion of individuals who sought dental care at the Family Health facilities in the previous three months. The persistence of barriers to access for other groups was identified by a significant proportion of individuals who needed dental care and have not demanded the FHS because of difficulties related to the services themself.

This study provided important information about dental service utilization in the working area of the FHS; however, some limitations affect its results. The study observed a cross-sectional design, which prevents causal inferences to be drawn from the associations currently reported. Another limitation is related to the possibility of response bias, since the findings are based on self-reports. Some respondents may have answered affirmatively when asked about recent dental visits so as not to appear negligent. Some respondents may also have had difficulties in giving precise answers to the questions asked.

According to Bostoen et al. ${ }^{39}$, usual sampling methods also involve limitations in surveys involving individuals living in settings with difficult access, such as poor peripheral urban areas and shantytowns. The absence of easily available sampling frames and difficult access to the population may reduce the ability to gather information and instruct health policies to groups with higher levels of need.

The study observed a relatively high nonparticipation rate ( $24 \%$ among adults and elderly people). Although refusal to participate was low, the interviews occurred during working hours of the ACS, as agreed with the City Health Department (Secretaria Municipal de Saúde), which limited participation, as some individuals were working and not at home. This observation explains the significantly higher participation of women in the sample, especially among adults, and individuals who do not work. Therefore, we cannot rule out selection bias in the current study.

Some areas were excluded due to the unavailability of the ACS to guide the research team, thus resulting in additional sampling losses. The main reasons for non-participation of the ACS were: absent from work for health reasons, vacations, or to participate in compulsory preparatory courses. In the non-excluded ACS working areas, some individuals were not interviewed because they did not reside in the selected households anymore; a high rate of residential mobility is usual found in the poorest areas of the city. Although most of the subjects selected were interviewed exclusively, and in spite of the absence of discrepancies in the socio-demographic characteristics between excluded and selected areas, special care should be taken if these results are to be applied to the entire FHS area in the city.

Despite these limitations, the study identified inequalities in the utilization of dental services, even in areas served by the FHS. Andersen's explicative framework made it possible to demonstrate the role of social and service-related determinants on access to dental care 12 . According to Andersen \& Davidson 12, apart from need factors and demographic variables, differences in the remaining sub-domains of the behavioral model point to the presence of inequitable access. In this study, socioeconomic factors and the presence of a regular source of dental care, in addition to age, were the main explanatory covariates for recent use of dental services. The complementary analysis, which focused on having a demand for a consultation met, selected the need-related variable as the only one statistically included in the multivariate model, which reinforces the hypothesis that poorer people remain with greater unmet dental needs even after looking for dental care.

The Andersen Behavioral Model instructed the other studies assessing individual determinants of dental service utilization for the specific age groups in this sample 25,26,27. The studies also exploited differences among individuals included in the adult group, since there are generally significant differences among young adults and older ones, in terms of oral health problems, perceived needs, and service utilization 25,26. However, Andersen's framework also states the 
hypothesis that community-level factors may additionally affect health care use 40 . Once the FHS is targeted to the poorest areas of the city, which share similar socioeconomic and service delivery system characteristics, the sample was considered as homogeneous at community-level. We suggest that further research may assess heterogeneous community contexts.

In conclusion, our results showed that although the FHS has been devised to improve the chances of the population having access to health services, there are important inequalities in the use and access to dental care. Health authorities should consider that socioeconomic inequalities continue to affect the use of health services, which remains favorable to better income groups, despite the expanded provision that involved the regulation of the FHS, and the principle of universal access included in the major health sector reforms that took place in the 1990s; and it seems to be related to difficulties of ensuring the FHDT as a regular source of dental care for all registered people. Therefore, these results reinforce the need to promote institutional incentives to improve access to dental care for underserved populations.

\section{Resumo}

O objetivo deste estudo transversal foi investigar a presença de desigualdades no acesso e uso de serviços odontológicos por pessoas residentes na área de abrangência da Estratégia Saúde da Família (ESF) em Ponta Grossa, Paraná, Brasil, e identificar os determinantes individuais relacionados. A amostra constou de 747 pessoas que responderam a um questionário pré-testado. Os dados foram analisados pelo teste qui-quadrado e regressão de Poisson, obtendo-se modelos explicativos para a utilização recente e limitando a análise àqueles que procuraram por tratamento odontológico para o acesso efetivo. Os resultados mostraram que $41 \%$ da amostra foi ao dentista recentemente. Menores proporções foram encontradas entre pré-escolares e idosos. Maior indicação da ESF como fonte regular de cuidados odontológicos ocorreu entre as crianças. Além da idade, melhor condição social e possuir um dentista regular associaram-se positivamente às consultas recentes. Foram identificadas desigualdades no acesso e uso de serviços odontológicos, o que reforça a necessidade de se promoverem ações que ampliem o acesso para a população de baixa renda.

Acesso aos Serviços de Saúde; Saúde Bucal; Desigualdes em Saúde

\section{Contributors}

M. H. Baldani was responsible for the design of the study; data analysis and interpretation; and writing up the article. J. L. F. Antunes was responsible for the study design, data analysis and interpretation; critical review of the article and approving the final version.

\section{Acknowledgments}

We would like to thank the local government of the municipality of Ponta Grossa, Paraná State, Brazil, and in particular the community health workers of the Family Health Strategy, for their assistance during data collection. We also wish to thank the students from UEPG for their valuable contribution to the data collection. This study received financial support from CNPq. 


\section{References}

1. Wilkinson RG, Picket KE. Income inequality and population health: a review and explanation of evidence. Soc Sci Med 2006; 62:1768-84.

2. Kenney GM, McFeeters JR, Yee JY. Preventive dental care and unmet dental needs among low-income children. Am J Public Health 2005; 95:1360-6.

3. Shi L, Stevens GD. Vulnerability and unmet health care needs: the influence of multiple risk factors. J Gen Intern Med 2005; 20:148:54.

4. Roberts-Thomson K, Brennan DS, Spencer AJ. Social inequality in the use and comprehensiveness of dental services. Austr J Public Health 2010; 19:80-5.

5. Hjern A, Grindefjord M, Sundberg H, Rosén M. Social inequality in oral health and use of dental care in Sweden. Community Dent Oral Epidemiol 2001; 29:167-74.

6. Barros AJD, Bertoldi AD. Desigualdades na utilização e no acesso a serviços odontológicos: uma avaliação em nível nacional. Ciênc Saúde Coletiva 2002; 7:709-17.

7. Varenne B, Petersen PE, Fournet F, Msellati P, Gary J, Ouattara S, et al. Illness-related behavior and utilization of oral health services among adult citydwellers in Burkina Faso: evidence from a household survey. BMC Health Serv Res 2006; 6:164.

8. Slack-Smith LM, Mills CR, Bulsara MK, O'Grady MJ. Demographic, health and lifestyle factors associated with dental services attendance by young adults. Austr Dent J 2007; 52:205-9.

9. Instituto Brasileiro de Geografia e Estatística. Acesso e utilização dos serviços de saúde - PNAD 1998. Rio de Janeiro: Instituto Brasileiro de Geografia e Estatística; 2000.

10. Instituto Brasileiro de Geografia e Estatística. Acesso e utilização dos serviços de saúde - PNAD 2003. Rio de Janeiro: Instituto Brasileiro de Geografia e Estatística; 2005.

11. Instituto Brasileiro de Geografia e Estatística. Acesso e utilização dos serviços de saúde - PNAD 2008. Rio de Janeiro: Instituto Brasileiro de Geografia e Estatística; 2010.

12. Andersen RM, Davidson PL. Improving access to care in America: individual and contextual indicators. In: Andersen RM, Rice TH, Kominski GF, Afifi AA, Rosenstock L, editors. Changing the U.S. health care system: key issues in health services policy and management. 3rd Ed. San Francisco: Jossey-Bass; 2000. p. 3-33.

13. Pinheiro RS, Viacava F, Travassos C, Brito AS. Gênero, morbidade, acesso e utilização de serviços de saúde no Brasil. Ciênc Saúde Coletiva 2002; 7:687-707

14. Aday LA, Andersen R. A framework for the study of access to medical care. BMC Health Serv Res 1974; 208-20.

15. Antunes JLF, Narvai PC. Políticas de saúde bucal no Brasil e seu impacto sobre as desigualdades em saúde. Rev Saúde Pública 2010; 44:360-5.

16. Baldani MH, Almeida ES, Antunes JLF. Equidade e provisão de serviços odontológicos no Estado do Paraná. Rev Saúde Pública 2009; 43:446-54.
17. Souza TMS, Roncalli AG. Saúde bucal no Programa Saúde da Família: uma avaliação do modelo assistencial. Cad Saúde Pública 2007; 23:2727-39.

18. Rocha RACP, Goes PSA. Comparação do acesso aos serviços de saúde bucal em áreas cobertas e não cobertas pela Estratégia Saúde da Família em Campina Grande, Paraíba, Brasil. Cad Saúde Pública 2008; 24:2871-80.

19. Pereira CRS, Patrício AAR, Araújo FAC, Lucena EES, Lima KC, Roncalli AG. Impacto da Estratégia Saúde da Família com equipe de saúde bucal sobre a utilização de serviços odontológicos. Cad Saúde Pública 2009; 25:985-96.

20. Departamento de Atenção Básica. Política Nacional de Atenção Básica. Brasília: Ministério da Saúde; 2006.

21. Coordenação Nacional de Saúde Bucal. Diretrizes da Política Nacional de Saúde Bucal. Brasília: Ministério da Saúde; 2004.

22. O'Donell O, Van Doorslaer E, Wagstaff A, Lindelow $M$. Analysing health equity using household survey data: a guide to techniques and their implementation. Washington DC: The International Bank for Reconstruction and Development/World Bank; 2008.

23. Andersen RM. Revisiting the behavioral model and access to medical care: does it matter? J Health Soc Behav 1995; 36:1-10.

24. Barros AJD, Hirakata VN. Alternatives for logistic regression in cross-sectional studies: an empirical comparison of models that directly estimate the prevalence ratio. BMC Medical Research Methodology 2003; 3:21.

25. Baldani MH, Brito VH, Lawder JAC, Mendes YBE, Silva FFM, Antunes JLF. Determinantes individuais da utilização de serviços odontológicos por adultos e idosos de baixa renda. Rev Bras Epidemiol 2010; 13:150-62.

26. Baldani MH, Mendes YBE, Lawder JAC, Silva FFM, Antunes JLF. Determinantes individuais da utilização recente de serviços odontológicos por adolescentes e adultos jovens de baixa renda. Pesqui Bras Odontopediatria Clín Integr; in press.

27. Baldani MH, Mendes YBE, Lawder JCA, Lara API, Silva MMA, Antunes JLF. Inequalities in dental services utilization among Brazilian low-income children: the role of individual determinants. J Public Health Dent; in press.

28. Departamento de Atenção Básica, Secretaria de Atenção à Saúde, Ministério da Saúde. Projeto SB Brasil 2003. Condições de saúde bucal da população brasileira, 2002-2003: resultados principais. Brasília: Ministério da Saúde; 2004.

29. Araújo CS, Lima RC, Peres MA, Barros AJD. Utilização de serviços odontológicos e fatores associados: um estudo de base populacional no Sul do Brasil. Cad Saúde Pública 2009; 25:1063-72.

30. Noro LRA, Roncalli AG, Mendes Junior FIR, Lima KC. A utilização de serviços odontológicos entre crianças e fatores associados em Sobral, Ceará, Brasil. Cad Saúde Pública 2008; 24:1509-16. 
31. Kramer PF, Ardenghi TM, Ferreira S, Fischer LA, Cardoso L, Feldens SCA. Utilização de serviços odontológicos por crianças de 0 a 5 anos de idade no Município de Canela, Rio Grande do Sul, Brasil. Cad Saúde Pública 2008; 24:150-6.

32. Pinheiro RS, Torres TZG. Uso de serviços odontológicos entre os estados do Brasil. Ciênc Saúde Coletiva 2006; 11:999-1010.

33. Camargo MBJ, Dumith SC, Barros AJD. Uso regular de serviços odontológicos entre adultos: padrões de utilização e tipos de serviços. Cad Saúde Pública 2009; 25:1894-906.

34. Lacerda JT, Simionato EM, Peres KG, Peres MA, Traebert J, Marcenes W. Dor de origem dental como motivo de consulta odontológica em uma população adulta. Rev Saúde Pública 2004; 38:453-8.

35. Ryan AS, Millstein SG, Greene B, Irwin CE. Utilization of ambulatory health services by urban adolescents. J Adolesc Health 1996; 18:192-202.

36. Ryan S, Riley A, Kang M, Starfield B. The effects of regular source of care and health need on medical care use among rural adolescents. Arch Pediatr Adolesc Med 2001; 155:184-90.
37. Mendoza-Sassi R, Béria JU, Barros AJD. Outpatient health service utilization and associated factors: a population-based study. Rev Saúde Pública 2003; 37:372-8.

38. Rosa Filho LA, Fassa AG, Paniz VMV. Fatores associados à continuidade interpessoal na atenção à saúde: estudo de base populacional. Cad Saúde Pública 2008; 24:915-25.

39. Bostoen K, Bilukha OO, Fenn B, Morgan OW, Tam CC, Veen A, et al. Methods for health surveys in difficult settings: charting progress, moving forward. Emerg Themes Epidemiol 2007; 4:13.

40. Andersen RM, Yu H, Wyn R, Davidson PL, Brown ER, Teleki S. Access to medical care for low-income persons: how do communities make a difference? Med Care Rev 2002; 59:384-411.

Submitted on 15/Jun/2010

Final version resubmitted on 21/Aug/2010

Approved on 13/Oct/2010 